\title{
Combining economic and social goals in the design of production systems by using ergonomics standards
}

\author{
Jan Dul, Henk de Vries, Sandra Verschoof, \\ Wietske Eveleens and Albert Feilzer
}

\begin{tabular}{|l|l|}
\hline \multicolumn{2}{|l|}{ ERIM REPORT SERIES RESEARCH IN MANAGEMENT } \\
\hline ERIM Report Series reference number & ERS-2004-020-LIS \\
\hline Publication & February 2004 \\
\hline Number of pages & 20 \\
\hline Email address corresponding author & j.dul@ffk.eur.nl \\
\hline Address & Erasmus Research Institute of Management (ERIM) \\
& Rotterdam School of Management / Rotterdam School of \\
& Economics \\
& Erasmus Universiteit Rotterdam \\
& P.O. Box 1738 \\
& 3000 DR Rotterdam, The Netherlands \\
& Phone: $\quad+31104081182$ \\
& Fax: $\quad+31104089640$ \\
& Email: info@erim.eur.nl \\
& Internet: $\quad$ www.erim.eur.nl \\
\hline
\end{tabular}

Bibliographic data and classifications of all the ERIM reports are also available on the ERIM website: www.erim.eur.nl 


\title{
ERASMUS RESEARCH INSTITUTE OF MANAGEMENT
}

\author{
REPORT SERIES \\ RESEARCH IN MANAGEMENT
}

\begin{tabular}{|c|c|c|}
\hline \multicolumn{3}{|c|}{ BIBLIOGRAPHIC DATA AND CLASSIFICATIONS } \\
\hline Abstract & \multicolumn{2}{|c|}{$\begin{array}{l}\text { In designing of production systems, economic and social goals can be combined, if ergonomics } \\
\text { is integrated into the design process. More than } 50 \text { years of ergonomics research and practice } \\
\text { have resulted in a large number of ergonomics standards for designing physical and } \\
\text { organizational work environments. This paper gives an overview of the } 174 \text { international ISO and } \\
\text { European CEN standards in this field, and discusses their applicability in design processes. The } \\
\text { available standards include general recommendations for integrating ergonomics into the design } \\
\text { process, as well as specific requirements for manual handling, mental load, task design, human- } \\
\text { computer-interaction, noise, heat, body measurements, and other topics. The standards can be } \\
\text { used in different phases of the design process: allocation of system functions between humans } \\
\text { and machines, design of the work organization, work tasks and jobs, design of work } \\
\text { environment, design of work equipment, hardware and software, and design of workspace and } \\
\text { workstation. The paper is meant to inform engineers and managers involved in the design of } \\
\text { production systems about the existence of a large number of ISO and CEN standards on } \\
\text { ergonomics, which can be used to optimize human well-being and overall system performance. }\end{array}$} \\
\hline \multirow{3}{*}{$\begin{array}{l}\text { Library of Congress } \\
\text { Classification } \\
\text { (LCC) }\end{array}$} & $5001-6182$ & Business \\
\hline & $5201-5982$ & Business Science \\
\hline & HD 62 & Standardization Production \\
\hline \multirow{3}{*}{$\begin{array}{l}\text { Journal of Economic } \\
\text { Literature } \\
\text { (JEL) }\end{array}$} & M & Business Administration and Business Economics \\
\hline & $\begin{array}{l}\text { M } 11 \\
\text { R } 4\end{array}$ & $\begin{array}{l}\text { Production Management } \\
\text { Transportation Systems }\end{array}$ \\
\hline & L 23 & Organization of Production \\
\hline \multirow{3}{*}{$\begin{array}{l}\text { European Business Schools } \\
\text { Library Group } \\
\text { (EBSLG) }\end{array}$} & $85 \mathrm{~A}$ & Business General \\
\hline & $\begin{array}{l}260 \mathrm{~K} \\
240 \mathrm{~B}\end{array}$ & $\begin{array}{l}\text { Logistics } \\
\text { Information Systems Management }\end{array}$ \\
\hline & $260 \mathrm{~N}$ & Production planning \\
\hline \multicolumn{3}{|c|}{ Gemeenschappelijke Onderwerpsontsluiting (GOO) } \\
\hline \multirow[t]{3}{*}{ Classification GOO } & 85.00 & Bedrijfskunde, Organisatiekunde: algemeen \\
\hline & $\begin{array}{l}85.34 \\
85.20\end{array}$ & $\begin{array}{l}\text { Logistiek management } \\
\text { Bestuurlijke informatie, informatieverzorging }\end{array}$ \\
\hline & 85.54 & Ergonomie \\
\hline \multirow[t]{3}{*}{ Keywords GOO } & \multicolumn{2}{|c|}{ Bedrijfskunde / Bedrijfseconomie } \\
\hline & \multicolumn{2}{|c|}{ Bedrijfsprocessen, logistiek, management informatiesystemen } \\
\hline & \multicolumn{2}{|c|}{$\begin{array}{l}\text { Productieprocessen, productieplanning, ergonomie, standaardisatie, normen bedriffskundige } \\
\text { techniek }\end{array}$} \\
\hline Free keywords & \multicolumn{2}{|c|}{$\begin{array}{l}\text { Production engineering, production planning, ergonomics, human factors, standard, } \\
\text { standardization, ISO, CEN, review }\end{array}$} \\
\hline
\end{tabular}




\section{Combining economic and social goals in the design of production systems by using ergonomics standards}

Jan Dul $^{1}{ }^{*}$, Henk de Vries ${ }^{1}$, Sandra Verschoof ${ }^{2}$, Wietske Eveleens $^{3}$, Albert Feilzer ${ }^{1}$

Version February 2004

\footnotetext{
${ }^{1}$ Department of Management of Technology and Innovation, Rotterdam School of Management, Erasmus School of Business, Erasmus University Rotterdam, Rotterdam, PO Box 1738, 3000 DR Rotterdam, The Netherlands.

${ }^{*}$ To whom correspondence should be addressed:

Prof.dr.ir. Jan Dul

Professor of Ergonomics Management,

Department of Management of Technology and Innovation,

Rotterdam School of Management,

Erasmus School of Business,

Erasmus University Rotterdam,

PO Box 1738, Room F2-59, 3000 DR Rotterdam,

The Netherlands.

Ph. + 31(0)10-4081719

Fax + 31(0)10-4089014

E-mail: j.dul@,fbk.eur.nl

Website: http://web.eur.nl/fbk/dep/dep6/members/dul

${ }^{2}$ Dutch Standardization Institute (NEN), PO Box 5059, 2600 GB, Delft, The Netherlands

${ }^{3}$ Eveleens Changing Workstyle, Postbox 8077, 3503 RB Utrecht, The Netherlands
} 


\begin{abstract}
In designing of production systems, economic and social goals can be combined, if ergonomics is integrated into the design process. More than 50 years of ergonomics research and practice have resulted in a large number of ergonomics standards for designing physical and organizational work environments. This paper gives an overview of the 174 international ISO and European CEN standards in this field, and discusses their applicability in design processes.

The available standards include general recommendations for integrating ergonomics into the design process, as well as specific requirements for manual handling, mental load, task design, human-computer-interaction, noise, heat, body measurements, and other topics.

The standards can be used in different phases of the design process: allocation of system functions between humans and machines, design of the work organization, work tasks and jobs, design of work environment, design of work equipment, hardware and software, and design of workspace and workstation.

The paper is meant to inform engineers and managers involved in the design of production systems about the existence of a large number of ISO and CEN standards on ergonomics, which can be used to optimize human well-being and overall system performance.
\end{abstract}

Keywords: production engineering, production planning, ergonomics, human factors, standard, standardization, ISO, CEN, review 


\section{Introduction}

There is an increasing interest of engineers and managers who are involved in designing production systems, to consider the worker as a human being rather than a 'necessary evil, soon to be replaced by robotics and automation' (Barnes \& Kay 2002). Human well-being can be combined with system productivity and reliability if attention is paid to human-centered design of production systems, using ergonomics principles. According to the International Ergonomics Association, which represents some 19000 ergonomists world-wide, ergonomics (or human factors) is "the scientific discipline concerned with the understanding of interactions among humans and other elements of a system, and the profession that applies theory, principles, data and methods to design in order to optimize human wellbeing and overall system performance'.

There is evidence that economic and social benefits can be reached if ergonomics is applied, as illustrated for example in this journal by Resnick \& Zanotti (1997) and Shikdar \& Sawaqed (2003), and in reviews by Hendrick (2003) and Vink, Van Rhijn, Dhondt \& Dul (1996).

Economic goals that have been reported are cycle time reductions, increased productivity, reduced production costs, high returns on investment, increased flexibility, increased product quality, increased innovativeness, reduced human and system errors, decrease in lost work time, reduced sick leave, reduced injury costs and drop in labor turnover. Social goals that have been reported are improved worker' health, reduced physical and mental work load, less pain and complaints, more comfort, less injuries, improved safety, improved motivation, and better work satisfaction.

It seems that combined economic and social benefits can be reached best, if ergonomics is applied in a broad sense, by realizing both technological and organizational improvements and innovations (Dul, Dhondt \& Vink, 1996b). During the last 50 years, ergonomics has developed rapidly as an independent science and profession, with its own knowledge, methods and networks. Scientists have published their knowledge in increasing numbers of ergonomics journals (Dul \& Karwowski, 2004). Professionals have applied ergonomics in the design of products and processes in many different branches of industry (Hägg, 2003). However, much of the ergonomics knowledge has not yet reached engineers and managers (Helander, 1999). 
When designing production systems, usually a stepwise design process is used. In the design approach according to ISO 6385 (Eveleens, 2003), these steps can be formulated as follows, where ergonomic inputs can be given in each design step:

1. Formulation of goals of the production system

2. Analysis and allocation of functions between human and technology

3. Design of the concept of the production system

4. Detailed design (the term 'work' is used in a broad sense)

- design of work organization

- design of work tasks

- design of jobs

- design of work environment

- design of work equipment, hardware and software

- design of workspace and workstation

5. Realization, implementation and validation

There are several ways to realize ergonomic inputs in this design process.

One way is to hire an ergonomics expert as a member of the design team (Eveleens, 1993). Another way is, that the design team uses practical guidelines taken from ergonomics handbooks (e.g. Kroemer \& Grandjean, 1997; Dul \& Weerdmeester, 2001), or uses official standards from standardization organizations.

This paper deals with the use of official ergonomics standards in the design process. In the last two decades a large number of ergonomics standards has become available. An overview is given of existing ergonomics standards. The paper is a follow up on the paper that was published in 1996 (Dul, De Vlaming \& Munnik, 1996a), when the number of published standards was roughly one quarter of the number in 2004.

This paper is meant to inform engineers and managers involved in designing productions systems about the existence of the large number of ISO and CEN ergonomics standards, and to discuss their applicability in design.

First, we will give some background information on the development of ergonomics standards during the last three decades. Then, we describe the way we selected the standards, how we classified the standards according to a typology given by De Vries (1998), and how we grouped the standards into different ergonomics topics. After the presentation of the results, we will discuss the application of ergonomics 
standards in the design process, comment on the legal status of certain European standards, and comment on future directions for ergonomics standardization.

\section{Background of ergonomics standards}

In the early 1970s, the International Ergonomics Association decided to initiate the development of ergonomic standards (Parsons \& Shackel, 1995). In 1974, the International Organization for Standardisation (ISO) established its Technical Committee TC 159 'Ergonomics' to formulate ergonomics standards in many different fields. In 1981, the first official standard on 'ergonomic principles in the design of work systems' (ISO 6385) was published.

In the 1980s, Europe developed towards a free internal market. To avoid unfair trade, common standards were desired, for example for the safety requirements of machinery. In 1989, the European Committee for Standardisation (Comité Européen de Normalisation, CEN) established the Technical Committee TC 122 'Ergonomics' to address ergonomics requirements in relation to safety of machinery. The first European ergonomics standard was published in 1990 as ENV 26385, which was an adoption of the above ISO 6385. Afterwards CEN has published ergonomics standards on safety of machinery and other ergonomics issues.

In the case of European standards, the national members of $\mathrm{CEN}$, being the national standardization bodies of countries of the European Union (EU) and the European Fair Trade Association (EFTA), have agreed to implement these standards in their national system and withdraw conflicting national standards. This obligation does not apply for ISO standards.

\section{Methods}

\subsection{Selection of standards}

Documents and websites from ISO and CEN, as well as additional information from the Dutch Standardisation Institute (NEN) and the Deutsches Institut für Normung (DIN) were used to collect data on the status of ergonomics standards (as of mid 2002, updated February 2004). Only standards from ISO TC 159 and CEN TC 122 were included. In other technical committees of CEN and ISO, specific ergonomics topics as part of another topics are covered as well (Dul et al. 1996a), but these standards were not considered. Also we did not consider standards developed by other standardization organizations than ISO or CEN, such as the International 
Electrotechnical Commission (IEC) and the European Telecommunication Standards Institute (ETSI).

Both published standards and standards in preparation were collected. ISO standards in preparation were selected if the draft standard was registered as a Committee Draft (CD), a Draft International Standard (DIS) or was a Final Draft International Standard registered for formal approval (FDIS). Working drafts were excluded since the content of such draft may still change considerably. CEN standards in preparation were selected if the current status was 'Under development', 'Under Approval' or 'Ratified'. Draft standards without a prEN-number were excluded. In the tables, the standards are listed according to increasing standard numbers.

\subsection{Classification of standards}

Standards were classified into 'horizontal standards' with requirements for a collection of applications, and 'vertical standards' with requirements for specific applications (De Vries, 1998). Also a distinction between 'basic standards', 'requiring standards', and 'measurement standards' was made (De Vries, 1998). 'Basic standards' contain for example terminology or basic data to facilitate communication between people on topics covered in standards. 'Requiring standards' put requirements on performance ('performance standards') or on solutions ('solution-describing standards'). 'Measurement standards' provide methods to check whether criteria in requiring standards have been met.

\section{Results}

Tables 1,2, 3, and 4, show the ergonomic standards that are available now.

\section{INSERT TABLE 1-4 ABOUT HERE}

It turns out that several CEN and ISO standards are identical. This is a result of a policy of CEN and ISO to harmonize the development of their standards, according to the Agreement on technical cooperation between ISO and CEN (Vienna Agreement) of 1991. In this agreement ISO and CEN decided to co-operate regarding general exchange of information, co-operation on standards drafting, and the adoption of existing international standards as European standards, and vice versa (Rensberger, Van de Zande, \& Delaney, 1997; CEN, 2004). 
In Tables 1-4, certain standards show up both as a published standard and as a standard in preparation. Then, the standard in preparation is a revision of the published standard. After publication, it will replace the existing standard. The current set of ergonomics standards contains both 'horizontal' (general) and 'vertical' (specific) standards. Examples of horizontal standards are ISO 6385 on ergonomic design principles, and EN 614 on ergonomics design principles for safety of machinery. Examples of 'vertical standards' are ISO 9241 on ergonomic requirements for visual display terminals, and ISO 11064-3 on control room lay out. Also 'basic', 'requiring' and 'measurement' standards show up in Tables 1-4. Examples of basis standards are terminology standards such as EN 1005-1, which includes terms and definitions on human physical performance, and ISO 10075, which includes terms and definitions on mental workload, or data standards such as ISO 15534-3, with data on human body dimensions.

With respect to 'Requiring standards' it appears that for most ergonomics standards it is difficult to make the difference between these performance standards and solution-describing standards. Examples of 'requiring standards' are ISO 9241 with requirements for visual display units, and ISO 11228 with requirements on manual handling.

Several standards are 'Measurement standards'. Examples are ISO 7726 on methods for measuring physical quantities of the thermal environment, and ISO/TS 13732-2 on methods for measuring human responses to contact with cold or hot surfaces.

In Table 5 the standards are organized according to ergonomics topics. Table 5 shows that the best covered topics are 'safety of machinery', 'physical environment' (noise, climate), 'workplace and equipment design', and 'visual information, VDT's and software' (VDT = visual display terminal, primarily for office work with computers).

\section{INSERT TABLE 5 ABOUT HERE}


Since the first ergonomics standard was published in 1981, the quantity of ergonomics standards has grown enormously. Nowadays 122 standards are published and 52 are in preparation (Table 6).

\section{INSERT TABLE 6 ABOUT HERE}

\section{Discussion}

\subsection{The application of ergonomics standards in design}

It turns out that majority of the current set of ergonomics standards are horizontal requiring standards. However, it seems that designers of production systems prefer vertical solution-describing standards when ergonomics criteria have to be taken into account in the design process. For example, Wulff, Westgaard \& Rasmussen (1999) found that designers of an engineering design team usually implemented specific design criteria, whereas general recommendations were usually not implemented. Their study suggests that designers do not understand general ergonomic recommendations, do not know how to make them concrete in the specific situations, or do not consider them important enough if they are in conflict with other design requirements.

Even though several ergonomics standard contain specifications for ergonomic solutions, specific technical solutions are not given, since the optimum solution depends on the organizational context. For example, the maximum load that a person can lift safely, not only depends on the mass of the load, but also on the handling frequency and duration, and on characteristics of the individual who have to perform the task.

Therefore, if a designer wants to apply the current set of ergonomics standards, he faces two problems. First, horizontal standards have to be selected and applied to the specific production situation. Second, requiring standards have to be translated to design solutions for the specific situation.

Although designers seem to prefer vertical solution-describing requirements to embed ergonomics knowledge in the design, ergonomics experts are concerned about the scientific quality of such standards, and seem to prefer horizontal performance standards. For example, Fallentin, Viikari-Juntura, Wærsted, \& Kilbom (2001) evaluated standards on physical workload and concluded that 'the 
scientific coherency of specific quantitative criteria was limited, whereas general process-type standards were more favorable'.

Since primarily ergonomics experts have developed the current set of ergonomics standards (Dul, Willemse \& De Vries, 2003), it is not surprising that most standards are horizontal requiring standards. These standards cannot be readily applied to specific situations without ergonomics knowledge. For several standards, ergonomics expertise from a designer (trough education or by studying the contents of a large set of standards) or from an external consultant is needed to translate the standards to specific design criteria.

\subsection{The legal status of certain European standards}

Although European standards are voluntary, national members of CEN are obliged to give these standards the status of a national standard, and withdraw conflicting national standards. Then, while the standards remain voluntary, they get a certain status in the market as national reference document. Moreover, within the so-called New Approach, several CEN standards are related to legislation in European Directives. These directives put generally formulated essential requirements on, for instance, safety, health, or environment. Linked to these directives, European standards are developed that give detailed requirements. A company that meets these standards is assumed to meet the general requirements set in the directives. Thus, implementing the standards is an effective and efficient way to meet the legal requirements. However, a company is allowed to meet these requirements in another way (Leibrock, 2002). Therefore, though principally voluntary, in practice, CEN standards can be "nearly obligatory'. Conformity to requirements in the directives is indicated by means of the $\mathrm{CE}$ mark (CE = Conformité Européenne) (Huigen, Inklaar \& Paterson, 1996).

With respect to European ergonomics standards, the first 16 ergonomics standards mentioned in Table 3, except for EN 1005-2, and including EN ISO 14738, are related to the Machinery Directive 98/37/EC (EU, 2003), which puts general requirements on safety of machinery.

\subsection{Future development of ergonomics standards}

Because of the high production of new standards in the last two decades, it seems that some duplication of work, inconsistencies and contradictions have occurred (Nachreiner, 1995). In future standards development a reduction of overlap, and more clear relationships between the standards are desirable. 
As mentioned before, ergonomics experts developed most standards, and probably belong to the most important user groups. However, according to the scopes of many ergonomics standards, other users are foreseen as well. For example, ISO 6385 stated that 'users of this standard will include managers, workers (or representatives), professionals such as ergonomists, project managers and designers who are involved in the design of work systems'. It is desirable that in the next decades of developing and revising ergonomics standards, other users than ergonomists, such as managers and designers of production systems, are more involved (Dul, et al. 2003).

\subsection{Research suggestions}

Future research on ergonomics standards could focus on the use of existing standards by design teams in order to answer questions such as "are the standards known", "are the standards used", and "are the standards considered to be useful?" Also research is needed on the development of ergonomics standards to address the coherence of the set of existing standards, the role of stakeholders in developing standards, and the possibilities to apply the standards without specific ergonomics knowledge.

Last of all, research is needed on the required conditions in organizations and contents of standards, such that ergonomics can be integrated in the design processes with minimum input of external ergonomics expertise, to achieve social and economic goals.

\subsection{Conclusions}

In the past 30 years a large number of ergonomics standards has been developed by ISO and CEN. Although standards are voluntary, certain CEN standards can be considered as 'nearly obligatory' because of their relationship with European legislation on safety of machinery.

Most standards apply to a variety of production systems ('horizontal standards'), and put requirements on the ergonomic performance of these systems ('requiring standards'). By applying ergonomics standards to specific production systems, social and economic benefits may be gained.

The current set of ergonomics standards does not include readily available technical solutions for specific production systems. Hence, for most standards, ergonomics 
expertise (partly available within the broad set of ergonomics standards) is needed to translate the standards to specific design criteria. 


\section{References}

Baines, T.S., \& Kay, J.M. (2002). Human performance modeling as an aid in the process of manufacturing system design: a pilot study. International Journal of Production Research 40 (10), 2321-2334.

CEN (2004) European Standardization in a Global Context. Brussels: European Committee for Standardization (CEN), $88 \mathrm{pp}$.

De Vries, H.J. (1998). The classification of Standards. Knowledge Organization, 25 (3), 79-89.

Dul, J., De Vlaming, P.M., \& Munnik, M.J. (1996a). A review of ISO and CEN standards on ergonomics. International Journal of Industrial Ergonomics, 17 (3), 291-297.

Dul, J., Dhondt, S., \& Vink, P. (1996b). Making companies more successful by balancing technological, organizational and human factors. In: O. Brown, \& H.W. Hendrick, Human Factors in Organizational Design and Management -V (pp.547550). Amsterdam, etc.: Elsevier Science.

Dul, J., \& Karwowski, W. (2004). An assessment system for rating journals in the field of ergonomics and human factors. Applied Ergonomics (in print).

Dul, J., \& Weerdmeester, B.A.(2001). Ergonomics for Beginners, $2^{\text {nd }}$ edition, London, New York: Taylor \& Francis.

Dul, J., Willemse, H., \& De Vries, H.J. (2003). Ergonomics standards: identifying stakeholders and encouraging participation. ISO-Bulletin, September, 19-23.

EU (2003). Commission communication in the framework of the implementation of Directive 98/37/EC of the European Parliament and of the Council of 22 June 1998 in relation to machinery amended by directive 98/79/EC, Official Journal of the European Union, C192, 2-29 
Eveleens, W. (1993). Preventive ergonomics; interdisciplinary co-operation between designers and ergonomists in systems designs. In: N.F.M. Roozenburg, Proceedings of the. 9th International Conference on Engineering Design ICED '93. Zürich: Heuristas.

Eveleens, W. (2003), A basic ergonomic standard. How to provide optimal working conditions for personnel. ISO-Bulletin, June, 3-6.

Fallentin, N., Viikari-Juntura, E., Waersted, M., \& Kilbom, A. (2001). Evaluation of physical workload standards and guidelines from a Nordic perspective. Scandinavian Journal of work environment and health, 27 (Suppl. 2), 1-52.

Hägg, G.H. (2003). Corporate initiatives in ergonomics - an introduction. Applied Ergonomics, 34 (1), 3-15.

Helander, M.G. (1999). Seven common reasons to not implement ergonomics. International Journal of Industrial Ergonomics, 25 (1), 97-101.

Hendrick, H.W. (2003). Determining the cost-benefits of ergonomics projects ans factors that lead to their success. Applied Ergonomics 34 (5), 419-427.

Huigen, H.W., Inklaar, A., \& Paterson E. (1997). Standardization and Certification in Europe. In: Wilfried Hesser \& Alex Inklaar (Ed.) An Introduction to Standards and Standardization, Beuth Verlag, Berlin, pp. 230-251.

Leibrock, G. (2002). Methods of referencing standards in legislation with an emphasis on European legislation. Enterprise Guides. Brussels: European Commission, Enterprise Directorate-General, Standardisation unit, $12 \mathrm{pp}$.

Kroemer, K.H.E., \& Grandjean, E. (1997). Fitting the task to the human. A textbook of occupational Ergonomics. London, etc.: Taylor \& Francis. 
Metz, B.G. (1991). Outcomes of international standardisation work in the field of ergonomics between 1975 and 1989. In: Y. Queinnec \& F. Daniellou, Designing for Everyone, Proceedings of the $11^{\text {th }}$ Congress of the International Ergonomics Association ( pp 978-980), London: Taylor \& Francis.

Nachreiner, F. (1995). Standards for ergonomics principles relating to design of work systems and to mental work load. Applied Ergonomics, 26 (4), 259-263.

Parsons, K.C., \& Shackel, B. (1995). Ergonomics and International Standards. History, organisational structure and method of development. Applied Ergonomics, $26(4), 249-258$.

Rensbergers, R.A., Van de Zande, R., \& Delaney, H. (1997). Standards setting in the European Union. NIST Special Publication 891, Gaithersburg: National Institute of Standards and Technology, $84 \mathrm{pp}$.

Resnick, M.L., \& Zanotti, A. (1997). Using ergonomics to target productivity improvements. Computers \& Industrial Engineering, 33 (1-2), 185-188.

Shikdar, A.A., \& Sawaqed, N.M. (2003). Worker productivity, and occupational health and safety issues in selected industries. Computers \& Industrial Engineering, 45 (4), 563-572.

Vink, P., Van Rhijn, G., Dhondt, S., \& Dul, J. (1996). Ten times better: improving technological, organizational and human factors in companies. In: O. Brown, \& H.W. Hendrick, Human Factors in Organizational Design and Management -V (pp.551-556). Amsterdam, etc.: Elsevier Science.

Wulff, I.A., Westgaard, R.H., \& Rasmussen, B. (1999). Ergonomic criteria in largescale engineering design-II Evaluating and applying requirements in the real work of design. Applied Ergonomics, 30 (3), 207-221. 


\section{Table 1: Published Standards from ISO TC 159}

ISO 6385:2004 Ergonomic principles in the design of work systems

ISO 7243:1989 Hot environments -- Estimation of the heat stress on working man, based on the WBGT-index (wet bulb globe temperature)

ISO 7250:1996 Basic human body measurements for technological design

ISO 7726:1998 Ergonomics of the thermal environment -- Instruments for measuring physical quantities

ISO 7730:1994 Moderate thermal environments -- Determination of the PMV and PPD indices and specification of the conditions for thermal comfort

ISO 7731:2003 Danger signals for work places -- Auditory danger signals

ISO 7933:1989 Hot environments -- Analytical determination and interpretation of thermal stress using calculation of required sweat rate

ISO 8996:1990 Ergonomics -- Determination of metabolic heat production

ISO 9241-1:1997 Ergonomic requirements for office work with visual display terminals (VDTs) -- Part 1: General introduction

ISO 9241-2:1992 Ergonomic requirements for office work with visual display terminals (VDTs) -- Part 2: Guidance on task requirements

ISO 9241-3:1992 Ergonomic requirements for office work with visual display terminals (VDTs) -- Part 3: Visual display requirements

ISO 9241-4:1998 Ergonomic requirements for office work with visual display terminals (VDTs) -- Part 4: Keyboard requirements ISO 9241-5:1998 Ergonomic requirements for office work with visual display terminals (VDTs) -- Part 5: Workstation layout and postural requirements

ISO 9241-6:1999 Ergonomic requirements for office work with visual display terminals (VDTs) -- Part 6: Guidance on the work environment

ISO 9241-7:1998 Ergonomic requirements for office work with visual display terminals (VDTs) -- Part 7: Requirements for display with reflections

ISO 9241-8:1997 Ergonomic requirements for office work with visual display terminals (VDTs) -- Part 8: Requirements for displayed colours

ISO 9241-9:2000 Ergonomic requirements for office work with visual display terminals (VDTs) -- Part 9: Requirements for nonkeyboard input devices

ISO 9241-10:1996 Ergonomic requirements for office work with visual display terminals (VDTs) -- Part 10: Dialogue principles ISO 9241-11:1998 Ergonomic requirements for office work with visual display terminals (VDTs) -- Part 11: Guidance on usability ISO 9241-12:1998 Ergonomic requirements for office work with visual display terminals (VDTs) -- Part 12: Presentation of information

ISO 9241-13:1998 Ergonomic requirements for office work with visual display terminals (VDTs) -- Part 13: User guidance ISO 9241-14:1997 Ergonomic requirements for office work with visual display terminals (VDTs) -- Part 14: Menu dialogues ISO 9241-15:1997 Ergonomic requirements for office work with visual display terminals (VDTs) -- Part 15: Command dialogues ISO 9241-16:1999 Ergonomic requirements for office work with visual display terminals (VDTs) -- Part 16: Direct manipulation dialogues

ISO 9241-17:1998 Ergonomic requirements for office work with visual display terminals (VDTs) -- Part 17: Form filling dialogues ISO 9355-1:1999 Ergonomic requirements for the design of displays and control actuators -- Part 1: Human interactions with displays and control actuators

ISO 9355-2:1999 Ergonomic requirements for the design of displays and control actuators -- Part 2: Displays

ISO 9886:2000 Evaluation of thermal strain by physiological measurements

ISO 9920:1995 Ergonomics of the thermal environment -- Estimation of the thermal insulation and evaporative resistance of a clothing ensemble

ISO 9921-1:2003 Ergonomic assessment of speech communication -- Part 1: Speech interference level and communication distances for persons with normal hearing capacity in direct communication (SIL method)

ISO 10075:1991 Ergonomic principles related to mental work-load -- General terms and definitions

ISO 10075-2:1996 Ergonomic principles related to mental workload -- Part 2: Design principles

ISO 10551:1995 Ergonomics of the thermal environment -- Assessment of the influence of the thermal environment using subjective judgement scales 
ISO 11064-1:2000 Ergonomic design of control centres -- Part 1: Principles for the design of control centres

ISO 11064-2:2000 Ergonomic design of control centres -- Part 2: Principles for the arrangement of control suites

ISO 11064-3:1999 Ergonomic design of control centres -- Part 3: Control room layout

ISO/TR 11079:1993 Evaluation of cold environments -- Determination of requisite clothing insulation (IREC)

ISO 11226:2000 Ergonomics -- Evaluation of static working postures

ISO 11228-1:2003 Ergonomics - Manual Handling - Part 1: Lifting and carrying

ISO 11399:1995 Ergonomics of the thermal environment -- Principles and application of relevant International Standards

ISO 11428:1996 Ergonomics -- Visual danger signals -- General requirements, design and testing

ISO 11429:1996 Ergonomics -- System of auditory and visual danger and information signals

ISO 12894:2001 Ergonomics of the thermal environment -- Medical supervision of individuals exposed to extreme hot or cold

environments

ISO 13406-1:1999 Ergonomic requirements for work with visual displays based on flat panels -- Part 1: Introduction

ISO 13406-2:2001 Ergonomic requirements for work with visual displays based on flat panels -- Part 2: Ergonomic requirements for flat panel displays

ISO 13407:1999 Human-centered design processes for interactive systems

ISO 13731:2001 Ergonomics of the thermal environment -- Vocabulary and symbols

ISO/TS 13732-2:2001 Ergonomics of the thermal environment -- Methods for the assessment of human responses to contact

with surfaces -- Part 2: Human contact with surfaces at moderate temperature

ISO 14738:2002 Safety of Machinery - Anthropometic requirements for the design of workstations at machinery

ISO 14915-1:2003 Software ergonomics for multimedia user interfaces - Part 1: Design principles and framework

ISO 14915-2:2003 Software ergonomics for multimedia user interfaces - Part 2: Multimedia navigation and control

ISO 14915-3:2003 Software ergonomics for multimedia user interfaces - Part 3: Media selection and combination

ISO 15534-1:2000 Ergonomic design for the safety of machinery -- Part 1: Principles for determining the dimensions required for openings for whole-body access into machinery

ISO 15534-2:2000 Ergonomic design for the safety of machinery -- Part 2: Principles for determining the dimensions required for access openings

ISO 15534-3:2000 Ergonomic design for the safety of machinery -- Part 3: Anthropometric data

ISO 15535:2003 General requirement for establishing anthropometric databases

ISO/TS 16071:2003 Ergonomics of human-system interaction - Guidance on accessibility for human-computer interfaces

ISO/TR 16982:2002 Ergonomics of human-system interaction -- Usability methods supporting human-centered design

ISO/TR 18529:2000 Ergonomics -- Ergonomics of human-system interaction -- Human-centered lifecycle process descriptions

ISO/TR 19358:2002 Ergonomics - Construction and application tests for speech technology

TR = Technical Report; TS = Technical Specification 


\section{Table 2 ISO Standards from ISO TC 159, in preparation}

ISO/DIS 7730 Ergonomics of the thermal environment - analytical determination and interpretation of thermal comfort using calculation of the PMV and PPD indices and local thermal comfort

ISO/FDIS 7933 Ergonomics of the thermal environment - analytical determination and interpretation of heat stress using calculation of the predicted heat strain

ISO/FDIS 8996 Ergonomics of the thermal environment - Determination of metabolic heat rate

ISO/CD 9241-10 Ergonomics of human system interaction -- Part 10: Dialogue principles

ISO/9920 Ergonomics of the thermal environment - Estimation of the thermal insulation and evaporative resistance of a clothing ensemble

ISO/CD 10075-3 Ergonomic principles related to mental workload -- Part 3: Measurement and assessment of mental workload

ISO/CD 11064-4 Ergonomic design of control centres -- Part 4: Layout and dimensions of workstations

ISO/CD 11064-6 Ergonomic design of control centres -- Part 6: Environmental requirements

ISO/CD 11064-7 Ergonomic design of control centres -- Part 7: Principles for the evaluation of control centres

ISO/CD 11079 Evaluation of the thermal environment -- Determination and interpretation of cold stress when using required

clothing insulation (IREQ) and local cooling effects

ISO/CD 11228-2 Ergonomics - Manual handling - Part 2: Pushing and pulling

ISO/CD 11228-3 Ergonomics - Manual handling - Part 3: Handling of low loads at high frequency

ISO/DIS 13732-3 Ergonomics of the thermal environment -- Touching of cold surfaces -- Part 3: Ergonomics data and guidance for application

ISO/CD 14505-1 Ergonomics of the thermal environment: Thermal environment in vehicles - Part 1: Principles and method for assessment for thermal stress

ISO/CD 14505-2 Ergonomics of the thermal environment: Thermal environment in vehicles - Part 2: Determination of equivalent temperature

ISO/CD 14505-3 Ergonomics of the thermal environment: Thermal environment in vehicles - Part 3: Evaluation of thermal comfort using human subjects

ISO/FDIS 15265 Ergonomics of the thermal environment - Risk assessment strategy for the prevention of stress or discomfort in thermal working conditions

ISO/DIS 15536-1 Ergonomics -- Computer manikins and body templates -- Part 1: General requirements

ISO/DIS 15536-2 Ergonomics -- Computer manikins and body templates -- Part 2: Structures and Dimensions ISO/DIS 15537

Principles for selecting and using test persons for testing anthropometric aspects of industrial products and designs

ISO/CD 15743 Ergonomics of the thermal environment - Working practices in cold: strategy for risk assessment and management

ISO/CD 20282-1 Ease of operations of everyday products -- Part 1: Context of use and user characteristics

ISO/CD 20282-2 Ease of operations of everyday products -- Part 2: Test method

ISO/PRF TS 20646 Ergonomic procedures for the improvement of local muscular loads

ISO/CD 20685 3D scanning methodologies for internationally compatible anthropometric databases

$C D=$ Committee Draft, registered draft standard; DIS = Draft International Standard, registered standard; FDIS = Final Draft International Standard registered for formal approval; TR = Technical Report; TS = Technical Specification. 


\section{Table 3: Published Standards from CEN TC 122}

EN 457:1992 Safety of machinery - Auditory danger signals - General requirements, design and testing (ISO 7731:1986 modified)

EN 547-1:1996 Safety of machinery - Human body measurements - Part 1: Principles for determining the dimensions required for openings for whole body access into machinery

EN 547-2:1996 Safety of machinery - Human body measurements - Part 2: Principles for determining the dimensions required for access openings

EN 547-3:1996 Safety of machinery - Human body measurements - Part 3: Anthropometric data

EN-563 1994/ Safety of machinery - Temperature of touchable surfaces - Ergonomics data to establish temperature limit values for hot surfaces

EN 614-1:1995 Safety of machinery - Ergonomic design principles - Part 1: Terminology and general principles

EN 614-2:2000 Safety of machinery - Ergonomic design principles - Part 2: Interactions between the design of machinery and work tasks

EN 842:1996 Safety of machinery - Visual danger signals - General design requirements, design and testing

EN 894-1:1997 Safety of machinery - Ergonomics requirements for the design of displays and control actuators - Part 1:

General principles for human interactions with displays and control actuators

EN 894-2:1997 Safety of machinery - Ergonomics requirements for the design of displays and control actuators - Part 2:

Displays

EN 894-3:2000 Safety of machinery - Ergonomics requirements for the design of displays and control actuators - Part 3: Control actuators

EN 981:1997 Safety of machinery - System of auditory and visual danger and information signals

EN 1005-1:2001 Safety of machinery - Human physical performance - Part 1: Terms and definitions

EN 1005-2 Safety of machinery - Human physical performance - Part 2: Manual handling of machinery and component parts of machinery

EN 1005-3:2002 Safety of machinery - Human physical performance - Part 3: Recommended force limits for machinery operation

EN ISO 7250:1997 Basic human body measurements for technological design (ISO 7250:1996)

EN ISO 7726:2001 Ergonomics of the thermal environment - Instruments for measuring physical quantities (ISO 7726:1998)

EN ISO 7730:1995 Moderate thermal environments - Determination of the PMV and PPE indices and specification of the conditions for thermal comfort (ISO 7730: 1994)

EN ISO 9241-1:1997 Ergonomic requirements for office work with visual display terminals (VDTs) - Part 1: General introduction (ISO 9241-1:1997)

EN ISO 9241-2:1993 Ergonomic requirements for office work with visual display terminals (VDTs) -- Part 2: Guidance on task requirements (ISO 9241-2:1992)

EN ISO 9241-3 :1993 Ergonomic requirements for office work with visual display terminals (VDTs) -- Part 3: Visual display requirements (ISO 9241-3:1992)

EN ISO 9241-4:1998 Ergonomic requirements for office work with visual display terminals (VDTs) - Part 4: Keyboard requirements (ISO 9241-4:1998)

EN ISO 9241-5:1999 Ergonomic requirements for office work with visual display terminals (VDTs) - Part 5: Workstation layout and postural requirements (ISO 9241-5:1998)

EN ISO 9241-6:1999 Ergonomic requirements for office work with visual display terminals (VDTs) - Part 6: Guidance on the work environment (ISO 9241-6:1999)

EN ISO 9241-7:1998 Ergonomic requirements for office work with visual display terminals (VDTs) - Part 7: Requirements for display with reflections (ISO 9241-7:1998)

EN ISO 9241-8:1997 Ergonomic requirements for office work with visual display terminals (VDTs) - Part 8: Requirements for displayed colours (ISO 9241-8:1997)

EN ISO 9241-9:2000 Ergonomic requirements for office work with visual display terminals (VDTs) - Part 9: Requirements for non-keyboard input devices (ISO 9241-9:2000) 
EN ISO 9241-10:1996 Ergonomic requirements for office work with visual display terminals (VDTs) - Part 10: Dialogue principles (ISO 9241-10:1996)

EN ISO 9241-11:1998 Ergonomic requirements for office work with visual display terminals (VDTs) - Part 11: Guidance on usability (ISO 9241-11:1998)

EN ISO 9241-12:1998 Ergonomic requirements for office work with visual display terminals (VDTs) - Part 12: Presentation of information (ISO 9241-12:1998)

EN ISO 9241-13:1998 Ergonomic requirements for office work with visual display terminals (VDTs) - Part 13: User guidance (ISO 9241-13:1998)

EN ISO 9241-14:1999 Ergonomic requirements for office work with visual display terminals (VDTs) - Part 14: Menu dialogues (ISO 9241-14:1995)

EN ISO 9241-15:1997 Ergonomic requirements for office work with visual display terminals (VDTs) - Part 15: Command dialogues (ISO 9241-15:1997)

EN ISO 9241-16:1999 Ergonomic requirements for office work with visual display terminals (VDTs) - Part 16: Direct manipulation dialogues (ISO 9241-16:1999)

EN ISO 9241-17:1998 Ergonomic requirements for office work with visual display terminals (VDTs) - Part 17: Form filling dialogues (ISO 9241-17:1998)

EN ISO 9886:2001 Evaluation of thermal strain by physiological measurements (ISO 9886:1992)

EN ISO 9920 Ergonomics of the thermal environment - Estimation of the thermal insulation and evaporative resistance of a clothing ensemble (ISO 9920:1995)

EN ISO 9921:2003 Ergonomics - Assessment of speech communication (ISO 9921:2001)

EN ISO 10075-1:2000 Ergonomic principles related to mental work-load - Part 1: General terms and definitions (ISO 10075:1991)

EN ISO 10075-2:2000 Ergonomic principles related to mental workload - Part 2: Design principles (ISO 10075-2:1996)

EN ISO 10551:2001 Ergonomics of the thermal environment - Assessment of the influence of the thermal environment using subjective judgement scales (ISO 10551:1995)

EN ISO 11064-1:2000 Ergonomic design of control centres - Part 1: Principles for the design of control centres (ISO 11064$1: 2000)$

EN ISO 11064-2:2000 Ergonomic design of control centres - Part 2: Principles for the arrangement of control suites (ISO 110642:2000)

EN ISO 11064-3:1999 Ergonomic design of control centres - Part 3: Control room layout (ISO 11064-3:1999)

ENV ISO 11079:1998 Evaluation of cold environments - Determination of required clothing insulation (IREC) (ISO/TR 11079:1993)

EN ISO 11399:2000 Ergonomics of the thermal environment - Principles and application of relevant International Standards (ISO 11399:1995)

EN 12515:1997 Hot environments - Analytical determination and interpretation of thermal stress using calculation of required sweat rate (ISO 7933:1989 modified)

EN ISO 12894:2001 Ergonomics of the thermal environment - Medical supervision of individuals exposed to extreme hot or cold environments (ISO 12894:2001)

EN 13202:2000 Ergonomics of the thermal environment - Temperatures of touchable hot surfaces - Guidance for establishing surface temperature limit values in production standards with the aid of EN 563

EN ISO 13406-1:1999 Ergonomic requirements for work with visual display based on flat panels - Part 1: Introduction (ISO 13406-1:1999)

EN ISO 13406-2:2001Ergonomic requirements for work with visual displays based on flat panels - Part 2: Ergonomic requirements for flat panel displays (ISO 13406-2:2001)

EN ISO 13407:1999 Human-centered design processes for interactive systems (ISO 13407:1999)

EN ISO 13731:2001Ergonomics of the thermal environment - Vocabulary and symbols (ISO 13731:2001)

EN 13861:2002 Safety of machinery - Guidance for the application of ergonomics standards in the design of machinery EN ISO 14738:2002 Safety of machinery - Anthropometric requirements for the design of workstations at machinery (ISO 14738:2002)

EN ISO 14915-1:2002 Software ergonomics for multimedia user interfaces - Part 1: Design principles and framework (ISO 14915-1:2002) 
EN ISO 14915-2:2003 Software ergonomics for multimedia user interfaces - Part 2: Multimedia control and navigation (ISO 14915-2:2003)

EN ISO 14915-3:2002 Software ergonomics for multimedia user interfaces - Part 3: Media selection and combination (ISO 14915-3:2002)

EN ISO 15535:2003 General requirements for establishing an anthropometric database (ISO 15535:2003)

ENV 26385:1990 Ergonomic principles of the design of work systems (ISO 6385: 1981)

EN ISO 27243:1993 Hot environments -- Estimation of the heat stress on working man, based on the WBGT-index (wet bulb globe temperature) (ISO 7243: 1989)

EN 28996:1993 Ergonomics - Determination of metabolic heat production (ISO 8996:1990)

ENV $=$ Preliminary European Standard 


\section{Table 4: Standards from CEN TC 122, in preparation}

prEN 614-1rev Safety of machinery - Ergonomic design principles - Part 1: Terminology and general principles. Under Approval prEN 894-4 safety of machinery - Ergonomics requirements for the design of displays and control actuators - Part 4: Location and arrangement of displays and control actuators. Under Development

prEN 1005-4 Safety of machinery - Human physical performance - Part 4: Evaluation of working postures and movements in relation to machinery. Under Approval

prEN 1005-5 Safety of machinery - Human physical performance - Part 5: Risk assessment for repetitive handling at high frequency. Under Approval

prEN ISO 6385 rev Ergonomic principles in the design of work systems (ISO/FDIS 6385:2003). Ratified

prEN ISO 7730 rev Ergonomics of the thermal environment - analytical determination and interpretation of thermal comfort using calculation of the PMV and PPD indices and local thermal comfort (ISO/DIS 7730:2003). Under Approval

prEN ISO 7933 Ergonomcis of the thermal environment - Analytical determination and interpretation of heat stress using calculation of the predicted heat strain (ISO/DIS 7933:2003). Under Approval

prEN ISO 8996 rev Ergonomics - Determination of metabolic heat production (ISO/DIS 8996:2003). Under Approval prEN ISO 9886 rev Ergonomics - Evaluation of thermal strain by physiological measurements (ISO FDIS 9886: 2003). Under Approval prEN ISO 9920 rev Ergonomics of the thermal environment - Estimation of the thermal insulation and evaporative resistance of a clothing ensemble. Under Development

prEN ISO 10075-3 Ergonomic principles related to mental workload - Part 3: Measurement and assessment of mental workload (ISO/DIS 10075-3:2002). Under Approval

prEN ISO 11064-4 Ergonomic design of control centers - Part 4: Layout and dimensions of workstations (ISO/DIS 11064-

4:2002). Under Development

prEN ISO 11064-6 Ergonomic design of control centers - Part 6: Environmental rerquirements for control centers (ISO/DIS 11064-6:2003). Under Approval

prEN ISO 11079 Evaluation of cold environments - Determination of required clothing insulation (IREQ) (will replace ENV ISO 11079:1998). Under Development

prEN ISO 13732-1 Ergonomics of the thermal environment - Methods for the assessment of human responses to contact with surfaces - Part 1: Hot surfaces (ISO/DIS 13732-1:2003). Under Approval

prEN ISO 13732-3 Ergonomics of the thermal environment - Touching of cold surfaces - Part 3: Ergonomics data and guidance for application (ISO/DIS 13732-3:2002). Under Approval

prEN 13921-1 Personal protective equipment - Ergonomic principles - Part 1: General requirements for the design and the specification. Under Approval

prEN 13921-3 Personal protective equipment - Ergonomic principles - Part 3: Biomechanical characteristics. Under Approval prEN 13921-4 Personal protective equipment - Ergonomic principles - Part 4: Thermal characteristics. Under Approval prEN 13921-6 Personal protective equipment - Ergonomic principles - Part 6: Sensory factors. Under Approval prEN 14386 Safety of machinery - Ergonomic design principles for the operability of mobile machinery. Under Approval prEN ISO 14505-1 Ergonomics of the thermal environment: Thermal environment in vehicles - Part 1: Principles and method for assessment for thermal stress. Under Development

prEN ISO 14505-2 Ergonomics of the thermal environment: Thermal environment in vehicles - Part 2: Determination of equivalent temperature. Under Development

prEN ISO 15536-1 Ergonomics - Computer manekins and body templates - Part1: General requirements (ISO/DIS 155361:2002). Under Approval

prEN ISO 15537 Principles for selecting and using test persons for testing anthropometric aspects of industrial products and designs (ISO/DIS 15537:2002). Under Approval.

prEN ISO 20685 3D scanning methodologies for internationally compatible anthropometric databases. Under Development prEN ISO 23973 Software ergonomics for World Wide Web user interfaces. Under Development 
stage between the beginning of the enquiry and the end of formal vote; Ratified = work item at a stage between ratification and publication; rev = standard under revision 
Table 5: Standards from tables 1-4, organized according to ergonomics topics

(standards can be listed under more than one topic)

1. General design principles

ISO 6385, ISO 13407

EN 614-1, prEN 614-1, EN 614-2, prEN ISO 6385, EN 13407, ENV 26385

2. Safety of machinery

ISO/FDIS 14738, ISO 15534-1, ISO 15534-2, ISO 15534-3

EN 457, EN 547-1, EN 547-2, EN 547-3, EN 563, EN 574 EN 614-1, prEN 614-1, EN 641-2 EN 842, EN 894-1, EN 894-2, EN 894-3, EN 894-4 EN 981, EN 1005-1, EN 1005-2, EN 1005-3, prEN 1005-4, prEN 1005-5, EN 13861, prEN 14386, prEN ISO14738

3. Physical environment

Noise/speech:

ISO 7731, ISO 9921-1, ISO 11428, ISO 11429 ISO/TR 19358

EN 457, EN 981, EN ISO 9921

Climate:

ISO 7243 ISO 7726 , ISO 7730 , ISO 7933 , ISO 8996 , ISO 9241-6, ISO 9886, ISO 9920, ISO 10551, ISO/TR 11079, ISO 11399, ISO 12894, ISO 13731, ISO/TS 13732-2, ISO/DIS 13732-3

EN 563, EN ISO 7243, EN ISO 7726. EN ISO 7730, prEN ISO 7730, prEN ISO 7933, EN ISO 8996, prEN ISO 8996, EN ISO 9241-6, EN ISO 9886, prEN ISO 9886, EN ISO 9920, prEN ISO 9920, EN ISO 10551, ENV ISO 11079, prEN ISO 11079, EN ISO 11399, EN 12515, EN ISO 12894, EN 13202, EN ISO 13731,prEN ISO 13732-1, prEN ISO 13732-3, prEN ISO 14505-1, prEN ISO 14505-2, EN ISO 27243, EN 28996

4. Physical work load

ISO 11226, ISO 11228-1

EN 1005-1, EN 1005-2, EN 1005-3, prEN 1005-4, prEN 1005-5

5. Mental work load

ISO 9241-2, ISO 10075, ISO 10075-2, ISO/CD 10075-3

EN 614-2, EN 9241-2, EN ISO 10075-1, EN ISO 10075-2, prEN ISO 10075-3

6. Workplace and equipment design

General:

ISO 9241-5, ISO 9241-6, ISO 11064-1, ISO 11064-2, ISO 11064-3

EN ISO 9241-5, EN ISO 9241-6, EN ISO 11064-1, EN ISO 11064-2, EN ISO 11064-3, prEN ISO 11064-4, prEN ISO 11064-6, prEN 14386

Anthropometry:

ISO 7250 , ISO 14738, ISO 15534-1, ISO 15534-2, ISO 15534-3, ISO 15535, ISO/DIS 15536-1, ISO/DIS 15537 EN 547-1, EN 547-2, EN 547-3, EN ISO 7250, EN 14738, EN ISO 15535, prEN ISO 15536-1, prEN ISO 15537, prEN ISO 20685

7. Visual information, VDT's and software

General:

ISO 9241-1, ISO 9241-2, ISO 9241-3, ISO 9241-4, ISO 9241-5, ISO 9241-6, ISO 9241-7, ISO 9241-8, ISO 9241-9, ISO 13406-1, ISO 13406-2, ISO 16071

EN ISO 9241-1, EN ISO 9241-2, EN ISO 9241-3, EN ISO 9241-4, EN ISO 9241-5, EN ISO 9241-6, EN ISO 9241-7, EN ISO 9241-8, EN ISO 9241-9, EN ISO 13406-1, EN ISO 13406-2 
Software:

ISO 9241-10 ISO 9241-11 ISO 9241-12 ISO 9241-13 ISO 9241-14 ISO 9241-15 ISO 9241-16 ISO 9241-17, ISO 13407, ISO 14915-1, ISO 14915-2, ISO 14915-3, ISO/TR 16982, ISO/TR 18529

EN ISO 9241-10, EN ISO 9241-11, EN ISO 9241-12, EN ISO 9241-13, EN ISO 9241-14, EN ISO 9241-15, EN ISO $9241-$ 16, EN ISO 9241-17, EN ISO 13407, EN ISO 14915-1, EN ISO 14915-2, EN ISO 14915-3, prEN ISO 23973

8. Displays and controls

ISO 9241-4, ISO 9355-1, ISO 9355-2, ISO 11428, ISO 11429

EN ISO 9241-4

9. Personal protection equipment

prEN 13921-1, prEN 13921-3, prEN 13921-4, prEN 13921-6 
Table 6 ISO and CEN standards on ergonomics

\begin{tabular}{|l|l|l|l|}
\hline & 1989 (Metz 1991) & $\begin{array}{l}1995 \text { (Dul et al. } \\
1996 \mathrm{a})\end{array}$ & 2004 (this paper) \\
\hline ISO published & 7 & 18 & 60 \\
\hline ISO in preparation & 14 & 31 & 25 \\
\hline CEN published & 0 & 10 & 62 \\
\hline CEN in preparation & 0 & 38 & 27 \\
\hline & & & 174 \\
\hline Total & 21 & 97 & \\
\hline
\end{tabular}




\section{Publications in the Report Series Research* in Management}

\section{ERIM Research Program: "Business Processes, Logistics and Information Systems"}

\section{4}

Smart Pricing: Linking Pricing Decisions with Operational Insights

Moritz Fleischmann, Joseph M. Hall and David F. Pyke

ERS-2004-001-LIS

http://hdl.handle.net/1765/1114

Mobile operators as banks or vice-versa? and: the challenges of Mobile channels for banks

L-F Pau

ERS-2004-015-LIS

http://hdl.handle.net/1765/1163

Simulation-based solution of stochastic mathematical programs with complementarity constraints: Sample-path analysis S. Ilker Birbil, Gül Gürkan and Ovidiu Listeş

ERS-2004-016-LIS

http://hdl.handle.net/1765/1164

* A complete overview of the ERIM Report Series Research in Management: https://ep.eur.nl/handle/1765/1

ERIM Research Programs:

LIS Business Processes, Logistics and Information Systems

ORG Organizing for Performance

MKT Marketing

F\&A Finance and Accounting

STR Strategy and Entrepreneurship 